\title{
Constructing E-learning Course of Business Japanese
}

\author{
Ziming Shi \\ Laboratory Center, Dalian University \\ Dalian, P.R.C. \\ Szm_zz@163.com
}

\author{
Hui Kang \\ Software School \\ Dalian University of Foreign Languages, Dalian, P.R.C. \\ cutekaitlyn@163.com
}

\begin{abstract}
This paper introduces the construction Business Japanese E-learning courses. By language “ASP.NET” and database tool "SQL", the E-learning Course is designed and established. Two platforms, namely, the front platform which acts as the interface with students, and the back platform which acts as the interface with teachers and administrators, are constructed with several modules each. This Business Japanese E-learning Course aims at enriching students' Business Japanese knowledge and enhancing their autonomous learning abilities, which also acts as the teachers' effective assistant. The teaching mode discussed in this paper also aims at providing a possible direction for conducting other subjects on campus.
\end{abstract}

Keywords-Business Japanese; E-learning; platform; autonomous learning

\section{INTRODUCTION}

In China With the spread of J-TEST and the increasing demands of the Japanese companies in China for talents with Japanese business knowledge, Business Japanese enjoys more and more care from the society. Compared with this situation, the content and teaching mode of Business Japanese Course in Chinese universities is relatively backward, being incompetent to follow the real advance of Business Japanese. With its various and enormous teaching content of dialogues, letters, special terms and standards, the course of Business Japanese can hardly meet students, demand in learning only depending on the teachers in-class teaching. To solve the problem of limited teaching time on huge amounts of teaching content, the e-learning course mode can be employed in teaching Business Japanese Course to students on campus.

\section{SUPPORTING THEORIES}

Constructionist holds the theory that individual learners construct mental models to understand the world around them. Besides, learning can happen most effectively when people are also active in making tangible objects in the real world. In this sense, experiential learning is most effective way of learning things [1]. To be specific Constructionists claim that learning is the process of students acquiring new knowledge through experiencing with the necessary instruction from the teachers. In other words, students are the main active body in information processing and knowledge construction, while teachers are the assistants and promoters. The traditional way can not effectively carry out the constructive learning process, therefore we resort to elearning.
E-Learning is the use of telecommunication technology to deliver information for education and training. With the progress of information and communication technology development, e-Learning is emerging as the paradigm of modern education [2]. Worldwide, the e-learning market has a growth rate of $35.6 \%$, but failures exist [3]. Some research early done shows that user satisfaction is one of the most important factors in assessing the success of system implementation [4]. In an e-Learning environment, several factors account for users' satisfaction. Those factors can be categorized into six dimensions: student, teacher, course, technology, system design, and environmental dimension [5] [6] [7]. On the basis of needs of the six dimensions mentioned above, the Business Japanese e-learning course discussed in this paper is constructed. Before the e-learning course is constructed, surveys are conducted to collect students' and teachers' need; relevant course content and course designs are carefully viewed; the features of developing tools and the real net environment are considered and the developing tools of "ASP.NET" and "SQL" are picked; and two platforms (front platform \& back platform) and three interfaces (for students, teachers, and administrators respectively) are designed.

\section{Present Condition of Business Japanese E- LEARNING COURSE}

In China and around the world, e-learning courses are of tremendous amounts, with a sharp increase every year. Yet the effective and professional e-learning courses are not many [3]. Presently in China Hujiang Net ranks no. 1 in developing Business Japanese E-learning Course in China. On Nov. 29, 2012 Hujiang Net signed the cooperation agreement with J. TEST in Shanghai and released their plan of developing a number of "J-TEST Courses Officially Recommended" in April of 2013. Although till the early time of 2014, there is no "J-TEST Courses Officially Recommended" release on Hujiang Net, their efforts on promoting Business Japanese E-learning Course are apparent.

\section{Tech Structure of Business JAPANESE E- LEARNING COURSE}

Business Japanese E-leaning course platform discussed in this paper is constructed on the basis of ASP.NET and SQL technology, and with two parts of the front platform and the back platform. The front platform is the interface with students. After students login in through the front platform, they can carry out the study activity of course material browsing, homework doing, self-checking, and 
improving by practicing on their weak aspects. The back platform is the interface with teachers and administrators, through which teachers release the teaching materials, input exercises, construct the papers, read students' homework, and monitor their study activities; and through which administrators manage the staff of students and teachers, the marks of the students exercises and test papers, and release announcements.

\section{A. The Front Platform}

The front platform focuses on stimulating students' ability of planning and managing their own study. It also aims at arousing students' interest and motivation in learning new knowledge. To achieve those goals, the front platform is equipped with several modules- "document browsing", "study management”, "survey filling”, "news browsing”, "test score checking”, "peer editing", etc. "Document browsing" module helps students review or preview the teaching materials related to the course that they pick. Documents include teaching slides, reference to the course, teaching videos, Business Japanese cases etc, by which means the students will pick up teaching content that is overlooked in class or further the learning in the field that they are interested in. "Study management" module enhances students self-learning ability. In this module, students learning trails are recorded for their reference. Their exercises scores and test scores are presented in form of pie chart or curves, through which the learners will get a clear idea of their learning process, such as where their weak points lie in, what their progress degrees are, where they have put their focus on. Besides, this module also recommends relevant learning strategies according to the learners' performance, instructing them where necessary. This module also instructs learners set their goals according to their actual situation. According to "Great Learning", learners need to bear clear goals in their mind before the learning actually starts. Only after the goals are set, can they understand what they want to do and carry their goals out without the other disturbances. When learners get a clear view of their learning process, their learning goal and the correspondent learning strategy in mind, they will bear a clear direction in learning Business Japanese. In addition, they will also have a sense of fulfillment when they find their progress and achievements in learning this subject. "Peer editing" module provides students with a platform of editing their peers' works, such as business letters, project presentations, project plan, etc. By doing peer editing, learners will enhance their readers' awareness and in turn make their own business writing proficient. Besides, editing among peers will also arouse students' interest and motivation because this method is different from the traditional way of teacher editing, and because the humorous and popular language they will have in the process of peer editing. Other modules also assist in students' self-learning: get the latest news on tests or announcements about the course of Business Japanese and check their test scores. The front platform also employs user friendly and interesting frame to arouse students' interest in Business Japanese Elearning Course.
Students' self-learning ability is of great importance to their learning in university, which can lead to their success both in university academic world and the preparation for their future life. By providing students with freedom in learning, the front platform can certainly promote students self-leaning ability.

\section{B. The Back Platform}

The back platform is the interface with teachers and administrators, functioning as learning monitoring, promoting and managing. To achieve the goals mentioned, seven modules are designed for the Business Japanese Elearning Course, namely, "learning monitoring”, “documents uploading”, "exercises pool building”, "papers constructing”, "papers grading”, "staff management", and "announcement releasing” modules.

The module of "learning monitoring" enables teachers to have an overall view of students' business Japanese elearning, on which the teachers may give their instructions and comments. Also teachers can score students on their elearning performance. Total autonomy in the process of elearning may result in the lack of authority instruction, thus deprive students of the right direction and necessary control in their learning. Once teachers play their role of instruction and monitoring through this module, students will know better of their weak points and where they need to get improved. They can also get the sense of achievement on teachers' praise, which will also act as the motivation in the Business Japanese e-learning.

The module of "document uploading" provides teachers with a means to upload the documents and files that they deem important and assisting in students' Business Japanese E-learning. For instance, the materials that are uploaded may be some teaching slides, the Business Japanese terms, some standards in J-TEST, the business negotiation videos, or some recommended books relating to this course. The documents and files are updated constantly to make sure of their immediacy. By choosing to view the uploaded business Japanese documents and files, the students will surely lay a solid foundation of their e-learning.

The module of "exercises pool building" is the foundation of the "test constructing" module. This Business Japanese E-learning Course not only provides e-learners with necessary course related materials, it also helps to check their learning by furnishing correspondent tests. To make the tests valid and credit, exercises making up tests are all from model J-TEST tests and test papers are constructed by choosing exercises from the exercises pool randomly. The random way of constructing test papers requires a large size of exercises pool, which is filled by teachers making model JTEST exercises. In the module of "exercises pool building", teachers upload J-TEST model exercises and sort them into different types and difficulty categories as the preparation for test papers constructing. When a test paper is constructed, exercises of certain types and numbers are abstracted from the "exercises pool" by different standards, such as the difficulty degree, the big columns needed, numbers of exercises in each columns and the mark of each exercise, etc. After learners finish the test, they can also get the keys and 
the instructions necessary, also from the exercises pool that the teachers have made.

"Paper grading" module is for teachers to read the writing or translation exercises. For the other tests, the platform will read them automatically by certain programs. In the students interface, there is one module of "peer editing". The "paper grading" module is for teachers to not only read students writing but also grade their "peer editing". That is to say for each writing, the score will be made up by two parts - the writing score (for their writing skills and performance) and the editing score (for their editing performance), through which way the learner will not only get the feedback on their writing but also on their peer editing too.

Other modules like "staff management" and "announcement releasing" are for administrators to manage the course related business mainly. "Staff management" module creates, delete or modify the learners' ID, password and other information, and sort them into different learning groups. "Announcement releasing" module mainly announces the latest test news or other related information.

\section{CONCLUSION}

Business Japanese teaching should not be limited to only on-class teaching, other form like E-learning Course is an effective alternative to lectures on class.

With the net compiling language of "asp.net" and the database tool "SQL" the E-learning Course is constructed with two platforms. The front platform which is the interface with students and is made up mainly by the modules of "documents browsing", "study management", "survey filling”, "news browsing”, "test score checking”, "peer editing”, etc. functions in assisting students browsing course related materials, carrying out certain learning activities, establishing their learning plan and strategies, and evaluate and adjust their Business Japanese E-learning. By providing students with different learning materials, strategies and learning instructions, the front platform enhances students' self-learning ability in the course of Business Japanese. The back platform is the interface with teachers and administrators, which assists in providing learning and exercises sources of Business Japanese for E-learning.

By means of Business Japanese E-learning Course, students have a wider chance of being exposed to various sources of Business Japanese, and more autonomy in their learning. This teaching mode not only enhances the efficiency of Business Japanese teaching, it also provides a reference teaching mode for other university subjects.

\section{ACKNOWLEDGMENT}

This paper is written with the support of Liaoning Fund for Planned Social and Science Programs "Construction of University English Writing Teaching and Feedback Network Platform”(No. L11DYY031), “Study on English Writing Feedback Behavior on the Basis of the Network Platform" (No. L12DYY014), "Study on Extracurricular Reading Autonomous Learning on the Basis of the Network Platform” (No. L13DYY064), the Scientific Research Fund Program of Dalian University of Foreign Languages "Research and Application of Project Based Teaching Method in IT English Writing Teaching on the basis of the Network Platform” (No. 2013XJQN28), and the Teaching Reform Project of Dalian University of Foreign Languages "Establishing and Application of English Intensive Course On-line Resources for IT Majored Students” (No. 2013Z0102 ).

\section{REFERENCES}

[1] Cakir, M, "Constructivist approaches to learning in science and their implications for science pedagogy: a literature review,” International Journal of Environmental \& Science Education, vol.3, 2008, 193-206.

[2] Pei-Chen Suna, Ray J. Tsaib, Glenn Fingerc, Yueh-Yang Chend, and Dowming Yeh, "What drives a successful e-Learning? An empirical investigation of the critical factors influencing learner satisfaction," Computers \& Education, vol. 50, May 2008, pp. 1183-1202.

[3] J.B. Arbaugh, R. Duray, "Technological and structural characteristics, student learning and satisfaction with web-based courses - An exploratory study of two on-line MBA programs," Management Learning, vol. 33, 2002, pp. 331-347.

[4] W. Delon, and E. Mclean, "Information systems success: the quest for the dependent variable,” Information Systems Research, vol. 3, 1992, pp. 60-95.

[5] J.B. Arbaugh, "Managing the on-line classroom: a study of technological and behavioral characteristics of web-based MBA courses,” Journal of High Technology Management Research, vo. 13, 2002, pp. 203-223.

[6] J.B. Arbaugh, and R. Duray, "Technological and structural characteristics, student learning and satisfaction with web-based courses - An exploratory study of two on-line MBA programs," Management Learning, vol. 33, 2002, pp. 331-347.

[7] W.L.C. Chen, and J.G. Bagakas, "Understanding the dimensions of self-exploration in web-based learning environments," Journal of Research on Technology in Education, vol. 34, 2003, pp. 364-373. 